\title{
Restorative Justice for Child Victim of Sexual Violence
}

\author{
Masrur Ridwan $^{1}$, Maryanto $^{2}$ \\ \{masrurridwan4@gmail.com¹, maryanto@unissula.ac.id²\} \\ Sultan Agung Islamic University, Jl. Kaligawe Raya No.KM, RW.4, TerboyoKulon, Genuk, Kota \\ Semarang, Jawa Tengah 50112, Indoensia
}

\begin{abstract}
Child sexual violence casualties continue to occur. The data of KPAI (Komisi Perlindungan Anak Indonesia/the Indonesian Child Protection Commission shows that over the past five years, there have been 412 cases of sexual violence in this country (2012), 343 cases in 2013, 656 cases in 2014, 218 cases in 2015, 120 cases in 2016, and 116 cases in 2017 (data until September). Efforts were made to reduce the number of victims, including aggravating criminal threats for perpetrators of such crimes, by altering or perfecting the rules deemed to be more protective of the victims. However, the rules that are more directed to the retributive system tend to ignore the rights of victims. This paper wants to illustrate how the victim of child sexual violence should pay attention to his rights. Some options or offers should be an option for child sexual violence victims. The results of the study show that the implementation of the Child Protection Act often hurts the victims' sense of justice. One of the cases was processed at the Banjarbaru District Court, Kalimantan Selatan, whereby the victim felt unfairly treated by the decision of the Panel of Judges, because although the victim and the defendant were in love, there was a peace deed between the defendant and the victim's family, and the victim was four months pregnant from the fruit of their love, but the panel of judges handed down the punishment according to the rules.
\end{abstract}

Keywords: Sexual Violence, Child Victim, Restorative Justice

\section{Introduction}

Child sexual violence casualties continue to occur. The data of KPAI (Komisi Perlindungan Anak Indonesia/the Indonesian Child Protection Commission shows that over the past five years, there have been 412 cases of sexual violence in this country (2012), 343 cases in 2013, 656 cases in 2014, 218 cases in 2015, 120 cases in 2016, and 116 cases in $2017[1]$

The cases of sexual violence for Kalimantan Selatan in the same time according to data in P2TP2A (Pusat Pelayanan Terpadu Pemberdayaan Perempuan dan Anak/the Integrated Service Center for Women and Children Empowerment) Banjarmasin reached 14 cases in 2012, 14 cases in 2013, 17 cases in 2014, 18 cases in 2015, 44 cases in 2016, and 37 cases in 2017. The number of victims of unregistered sexual violence and not reporting due to embarrassment or other reasons are believed to be more than that[2].

Various efforts were made to reduce the number of victims, including aggravating criminal penalties for the perpetrators of such crimes, by altering or perfecting the rules deemed to be more protective of the victims[3]. However, the field findings indicate that, in some instances, a more severe threat or criminal judgment on the defendant is treated as suffering by victims who feel unfairly treated. Moreover, not infrequently the role of victims in child sexual violence cases is often dominant, even decisive. In such cases, there should be an option or offer deemed best for the future of the victim. The problem is, 
giving such a choice or offer to child sexual violence victims is not possible as long as our rule of law is more directed to a retributive system[3].

On the other hand, sexual violence of children passed through old wedding dispensation continues to increase. For the year 2017 (September data) in Kalimantan Selatan is more than 8,000 children who get married dispensation early. This study wants to encourage the application of restorative justice for victims of child sexual violence.

\section{Methodology}

The study used in this paper is a sociological juridical (juridical empirical) study, which uses legal norms and legal documents of child protection in Indonesia as preliminary data, followed by primary data as the main study material. The study was conducted analytically and descriptively by revealing the factors that influence the sense of justice of the victim of child sexual violence, both before and after the court decision. The location of the study is in Kalimantan Selatan, and the verdict of Banjarbaru district court is one of the samples of cases. The province in recent years has always ranked top in terms of early marriage in Indonesia.

\section{Findings}

\subsection{Cases of Child sexual violence and the Rules of Law}

Cases of child sexual violence in Kalimantan Selatan occur evenly in almost all districts and cities. Cases of child sexual violence in this province may be highly correlative with early marriage rates which in recent years have been the highest category in Indonesia for children under 15 years of age. The latest data from BKKBN (Badan Kependudukan dan Keluarga Berencana Nasional/National Population and Family Planning Agency) shows that early marriage rate in South Kalimantan reaches 51/1.000 residents, well above the national average of $40 / 1.000$ residents. If presented at 9, 24 percent, with criteria 10 to 14 years of 5.7 percent and age 15 to 19 years, it increases as much as 46 percent. The ratio of early marriage in Kalimantan Selatan even reached 33.68 percent. That means one in three women in Kalimantan Selatan married underage. Some of the causes of high rates of early marriage, in addition to economic factors, low levels of education, the environment, and culture are also due to the influence of mobile phones and the rapid development of social media.

Looking at the data above, it is not impossible that cases of child sexual violence to be processed to court started from the parent's refusal of the relationship of the perpetrator and the victim, whatever the cause. Due to the disapproval of the parents, the perpetrator and the victim finally opted to sexual intercourse, without thinking about the impact. This means that cases of child sexual violence do not always begin with malicious intent. Child sexual violence often starts from the accelerated aggression of the "biological maturity" due to the internet or on the basis of love while the law enforcement process by law enforcement officers is always more focused on how to prove the occurrence of child sexual violence, which continues on the procedure of settlement of crime through the criminal law.

When a person is brought to court on the charge of child sexual violence, it may be the beginning of the suffering that the victim of child sexual violence must undergo. When a criminal verdict has been handed down to the perpetrator, not infrequently, what happens is the actual long-suffering of the victim. By the time the judicial process is over, the law 
enforcement officers no longer care about the victims. The attention of law enforcement officers to child sexual violence victims completed with the end of the victim's testimony in court. The testimonies and statements taken from victim-witnesses are only those supporting the verification of the indictment proof. Those related to the victims' interests were ignored. As a result, the criminal verdict imposed not only burdensome the defendant, but also often considered unfair by the victim.

Article 81 and Article 82 of the Law on Child Protection (Law No. 17 of 2016 on Stipulation of Government Regulation in Lieu of Act No. 1 of 2016 on the Second Amendment to Law No. 23 Year 2002 on Child Protection into Law) affirms that everyone who is proven to have sexual intercourse with a minor shall be subjected to imprisonment for a minimum of five years and a maximum of 15 years. The rules do not care who takes the initiative to have intercourse, but because it has not included in complaint offenses, the law apparatus, both the police and the prosecutor, must proceed to the court, and the judge must hand down the punishment, which is difficult to accept by both defendant and victim.

Two cases of juvenile intercourse processed at the Banjarbaru District Court are fascinating to be raised as case studies in the study of child sexual violence. First, court verdict with case number 187 / Pid.Sus / 2014 / PN.Bjb, with an adult offender. Second, court verdict with number 62 / Pid.Sus / 2014 / PN.Bjb, with child offender.

The Public Prosecutor's demand in the first case is a prison sentence of seven years imprisonment, reduced by the period of temporary detention, with a fixed order in detention and a fine of Rp 60,000,000 (sixty million rupiahs) or replaced with three months of confinement. That is by Article 81 Paragraph (2) of the Law of the Republic of Indonesia concerning Child Protection. The Panel of Judges in a decision dated September 18, 2014, imposed a jail term of up to three years in prison and a fine of Rp 60,000,000 (sixty million rupiahs) or replaced with two months of confinement. The verdict of the panel of judges is a minimum criminal under the provisions of the Child Protection Act before the amendment (Law No. 23 of 2002).

This case is both exciting and disturbing the sense of justice, especially for the victim who was then aged 15 years. The victim is forced to undergo solitude after a loved one has to undergo punishment, while the womb has grown a fetus due to her lovemaking with the perpetrator. The Chief Judge read out the criminal verdict while shedding tears, knowing that between the victim and the defendant loved each other and there was already a deed of agreement between the defendant and the victim's family, while the victim was four-months pregnant. However, the panel of judges has no choice but to punish by the general provisions.

The Prosecution of The Child Prosecutor in The second case is three years term, reduced a temporary detention period, plus a fine of $\mathrm{Rp} 60,000,000$ (sixty million rupiahs), or replaced with three months of vocational training. The sole judge of child case in a decision dated May 7, 2014, imposed a one year and eight months imprisonment, minus a period of temporary detention and a fine of $\mathrm{Rp} \mathrm{60,000,000} \mathrm{(sixty} \mathrm{million} \mathrm{rupiahs),} \mathrm{or} \mathrm{replaced} \mathrm{by} \mathrm{two}$ months of vocational training.

This case is also interesting to be a case study of child sexual violence. It was revealed in court, although not pregnant, because of their intercourse case was brought to court, the 15 -year-old victim did not want to go home, no longer willing to continue school. She chose to work in a bakery and gave some of her income to the perpetrator who was in prison.

The question is, how different are they with couples who do early marriage? Did not they do child sexual violence too? If the answer is that the early marriage offenders already get 
dispensation for marriage, why can not the victim of child sexual violence get the same dispensation?

\subsection{Rights and Interests of Victims}

Two cases of child sexual intercourse are processed in the Banjarbaru State Court qualitatively can be a study as well as reflection for all parties. During this time, people often think that by severely punishing the perpetrators of child sexual violence, people will be afraid to do the same. The thought was not entirely true. Proved by the increasing number of victims of child sexual violence every year, both of them are victims of sexual intercourse of children due to rape, victims who want (lovers), as well as victims who get legalized for dispensation. The child population victims who were tried in Banjarbaru District Court got a streak of bad luck.

The marginalization of the victim's interest in settling cases of child sexual violence through criminal law can not be separated from the dominance of retributive paradigm in the establishment and application of criminal law. As a consequence of such law enforcement, it can not be denied that the enforcement of order causes injustice. This is different from restorative justice which emphasizes the principle of balance of interests of the perpetrator, victim, and society because the direction to be achieved is a more substantial resolution of the conflict. At least, there is a feedback of taking and give process both economically and empathetically.

Restorative justice is also closely linked to the application of empowerment, which gives the victim the freedom to choose the alternatives available to solve her problems, and the decision to vote is available in the process of restorative justice. Empowerment also provides an opportunity for the victim to play a role in the entire process, and defines the victim's own needs and how and when the needs should be met[4]. The victim is the party who knows better what is needed because her voice should be heard and her needs should be taken care of. In this context, the courts can act as public order keepers, and society plays a role to preserve a just peace.

\subsection{The Reality of Restorative JusticeUnderstanding}

The understanding of restorative justice in Indonesia is still far from adequate. The statements are already understood together and are even applied to law enforcement officers. The orientation of law enforcement officers in criminalizing is more focused on offender-oriented and criminal settlement procedures through criminal law. Victim's suffering or loss is ignored. Victims are also not enabled to determine how the conflict is resolved actively. Attitudes and actions of law enforcement officers who carry out criminal proceedings often result in other victims of the victim (secondary victimization).[5]

The concept of such criminal law, making the victim's wishes related to the settlement of the crime that befell him becomes less accommodated in the rule of law. Hence, although the suffering or loss caused by the crime are those of the victim must endure, the focus of restoration of justice is opted to be undergoing a diversion process through which private interpersonal resolution of the offender and the victim is the ultimate solution[5]. Law enforcement officials feel that they have "upheld justice" if they have completed the judicial process and impose criminal sanctions on the perpetrators.

Such judicial settlement processes will only meet one side of the interests of justice seekers in order for a law to be enforced, but the more critical side for justice seekers, i.e., they want to be helped out of trouble, will be even more challenging to achieve. 


\section{Conclusion}

The ultimate purpose of law enforcement is justice. However, in some instances, the application of restorative justice for the child sexual violence victims, are imperative to be considered as the primary choice. The perpetrators of early marriage are included in the category of child sexual violence victims. If the perpetrators of early marriage can be legalized by dispensation, the same treatment should also apply to victims of sexual violence of children based on love who want to get married soon. The victim is the most disadvantaged person in the case of child sexual violence, so it is fair if the victim becomes the first person to be heard, whose needs should be fulfilled. It can be realized if the punishment mechanism implements a restorative justice system.

\section{References}

[1] L. . . [et. al. Rumble, "Childhood Sexual Violence in Indonesia: A Systematic Review," Trauma, Violence, Abus.

[2] ECPAT Indonesia, "Global Study on Sexual Exploitation of Children in Travel and Tourism," Jakarta, 2016

[3] J. K. and C. J. T. K, Riedl ; "Restorative Justice in Children," Curr. Biol., vol. 25, no. 13, pp. 1731-1735, 2015.

[4] S. J. M. and H.-H. T, "Victims of Child Sexual Abuse: Understanding Their Need for Justice," Int. J. Law, Crime, Justice, vol. 54, pp. 11-20, 2018.

[5] S. A, "Human Rights and Restorative Justice," in International Handbook of Restorative Justice Routledge T Gavrielidesed, New York: Routledge, 2018, pp. 60-70. 